\title{
Immigrant entry earnings over the past quarter- century: The roles of changing characteristics and returns to skills
}

\author{
Feng $\mathrm{Hou}^{1}$
}

\begin{abstract}
This study examines whether factors associated with the rise in the Canadian-born - recent immigrant earnings gap played different roles in the 1980s, 1990s, and early 2000s. The results show that for recent immigrant men, shifts in population characteristics had the most important effect in the 1980s, when the earnings gap expanded the most, but this compositional effect diminished in the 1990s and early 2000s. The effect of changes in returns to Canadian experience and education was small for men in all three periods. During the early 2000s, the IT bust, combined with a heavy concentration of immigrants in IT-related occupations, was the primary explanation of the increase in their earnings gap.
\end{abstract}

Keywords: Immigrants, entry earnings, decomposition, Canada.

\section{Résumé}

Cette étude examine si les facteurs associés à la hausse des écarts de revenus entre les nouveaux immigrants et les gens nés au Canada ont joué des rôles différents dans les années 1980, 1990 et au début des années 2000. Les résultats indiquent que chez les nouveaux immigrants masculins, les effets des changements dans la population se sont le plus fait sentir dans les années $1980 \mathrm{au}$ moment où les écarts de revenus étaient les plus importants; cet effet compositionnel a cependant diminué dans les années 1990 et au début des années 2000. L’effet des changements sur le plan des retours à l'expérience et l'éducation canadiennes fut modeste pour les hommes durant ces trois périodes. Au début des années 2000, l'effondrement du secteur de la TI, allié à la forte concentration d'immigrants travaillant dans des professions connexes, fut la principale explication de l'augmentation de cet écart de revenus.

Mots-clés : immigrants, revenus d'entrée sur le marché du travail, décomposition, Canada.

\section{Introduction}

Many studies have documented the deteriorating labour market performance of recent immigrants in Canada through the 1980s and 1990s (Bloom et al. 1995; Picot and Hou 2003; Aydemir and Skuterud 2005; Frenette and Morissette 2005). This deterioration has continued despite the improved macroeconomic condition in the early 2000s and rising educational attainment of immigrants (Picot et al. 2008).

1 Feng Hou, Social Analysis Division, Statistics Canada, 100 Tunney’s Pasture Driveway, Ottawa ON K1A 0T6. Email: feng.hou@statcan.gc.ca. 
No consensus has been reached in the literature regarding whether the decline in the entry earnings of recent immigrants relative to the Canadian-born is associated mostly with changes in population characteristics or changes in Canadian labour market conditions (e.g., Reitz 2001; Aydemir and Skuterud 2005; Boudarbat and Lemieux 2010; Green and Worswick 2010). There are at least two possible reasons why previous studies came to somewhat different conclusions. First, various explanatory factors might have played a different role during different periods. This possibility has not been carefully explored in previous studies. Second, methodological differences might contribute to the variation in the results. Notably, the inconsistent use of decomposition techniques could accentuate the role of some factors over others.

This paper is intended to contribute to the literature in two ways. First, it examines the varying impact of compositional shifts and changing returns to skills (education and experience) on the entry earnings gap for recent immigrants separately for three periods, the 1980s, 1990s, and early 2000s. The three periods correspond to some significant changes in immigration policies and macroeconomic conditions in Canada. The 1980s witnessed a drastic shift in the source regions of new immigrants, as a result of the implementation of a non-discriminatory immigration selection policy. In the 1990s, selection regulations were further modified to enhance a "human capital approach," and education levels among entering immigrants improved significantly. Labour market conditions in the 1980s and early 1990s were unfavorable to new labour market entrants, whose earnings declined relative to older workers. This "new entrant" effect could affect recent immigrants and young Canadian-born alike. In the late 1990s and early 2000s, the information technology (IT) sector experienced a boom and a bust, and this fluctuation affected new immigrants severally because of their high concentration in that sector (Picot and Hou 2009). Thus, the impact of policy changes (a main determinant of immigrant composition) and labour market conditions on immigrants' entry earnings was unlikely to remain the same over these periods. A better understanding of their changing effects would help us anticipate the labour market outcomes of future new immigrants, and the possible effectiveness of any further modifications in immigration selection policies.

The second contribution is methodological. The analysis uses a flexible model specification that can simultaneously capture the effects of both compositional shifts and changes in returns to education and experience on the trend in immigrants' entry earnings gap. This model specification allows the use of a decomposition technique that deals with the possible overlapping effects of various explanatory factors. This approach differs from earlier research, which tended to enter one factor at a time. The order in which different explanatory variables are entered may affect the decomposition results.

\section{Explaining the declining entry earnings of immigrants}

\section{Potential explanatory factors and their changing roles}

Previous studies have identified two major factors underlying the deteriorating labour market outcomes of recent immigrants (Picot and Sweetman 2005; Reitz 2007a, 2007b). The first is changes in immigrant composition, particularly the shift in source countries of immigration from Europe and the United States to other regions, and the associated changes in immigrants' proficiency in Canada's official languages (Picot and Hou 2003; Aydemir and Skuterud 2005). Immigrants from countries other than the United States and Europe may have lower earnings, because potential difficulties related to language, education quality, social networks, and possibly discrimination may reduce the transferability of their skills and credentials (Bloom et al. 1995; Sweetman 2004). Aydemir and Skuterud 
(2005) suggest that these compositional changes were responsible for about one-third of the decline in entry earnings of recent immigrant men from the late 1960s to the late 1990s. In comparison, Green and Worswick (2010) show that changes in source regions and education account for about one-tenth of the decline in entry earnings of immigrant men from the early 1980s to the early 2000s.

It is highly likely that compositional changes had the most negative effect on immigrant entry earnings in the 1980s, when a large shift from traditional source regions to non-Western countries occurred yet the educational levels of new immigrants increased little (Reitz 2001). After the 1980s, any negative effect of the continuing small shift in source regions was likely offset by the rapidly rising educational levels among new immigrants resulting from new policy initiatives adopted in the early 1990s to select more highly educated immigrants. With a steady annual immigration intake around 225,000 over the 1990s, the number of immigrants with university degrees rose from around 30,000 in 1990 to 78,000 by 2000, remaining stable after that time (Picot and Hou 2009).

The second factor that may influence the immigrant entry earnings gap is some long-term changes in labour market conditions, which could affect both the Canadian-born and immigrants. Based on an earlier observation that real wages fell 20 per cent among Canadian new labour market entrants from 1981 to 1993 (Beaudry and Green 2000), Green and Worswick (2004) concluded that the best benchmark against which to compare immigrant earnings was the Canadian-born new labour market entrants. This was an ingenious effort to allow the wage structure for new labour market entrants (including immigrants) to change over a period as long as two decades, rather than assuming that it remained fixed. Green and Worswick (2010) find that the broader deterioration in earnings for new entrants accounted for about 40 per cent of the total decline in immigrant entry earnings from the 1980-82 cohort to the 2000-02 cohort. It is likely that this factor was more important before the late 1990s than after. The outcomes for new labour market entrants-particularly young men, among whom the decline was largely observed-had stopped deteriorating during the late 1990s and early 2000s (Morissette 2008). Boudarbat et al. (2010) also find that after years of expansion, the earnings gap between young and old workers stabilized by the mid-1990s.

Some researchers also emphasize the role played by changes in the earnings return to immigrantspecific characteristics. While Aydemir and Skuterud (2005) and Green and Worswick (2010) focus on the declining returns to foreign work experience, Reitz (2001) stresses changes in returns to foreign education. It is difficult to discern statistically whether changing returns to these foreignacquired skills are due to the declined quality of these skills or to reduced demand for these skills as a result of changes in the Canadian labour market. However, if changes in returns to foreign work experience and immigrant education were not consistent over the 1980s, 1990s, and early 2000s, e.g., increased in one period but decreased in another, the cause is more likely related to fluctuations in labour market demand. In any case, as will be discussed later, it is difficult to disaggregate the individual contribution of changes in returns to immigrant education and foreign experience to the decline in immigrants' relative entry earnings.

\section{Analytical approach of the present study}

The present study focuses on cross-cohort differences in immigrants' entry earnings relative to the Canadian-born. Examining immigrant entry earnings is important for several reasons. Immigrant entry earnings and other initial labour market outcomes are often used as a criterion to evaluate the effectiveness of immigration selection programs, and to make policy adjustments (Green and Worswick 2010). Economic outcomes during the early years after arrival may affect immigrant decisions on whether to remain in Canada, move to other countries, or return to their source country. 
Information on initial outcomes is likely transmitted to would-be immigrants in the source countries, potentially affecting their choice of destination countries.

Focusing on entry earnings allows us to use a very flexible model that includes changes in the return to both Canadian work experience and education as explanatory factors. Changes in the return to Canadian work experience capture both the new labour market entrant effect introduced by Green and Worswick (2010) and the improved earnings position of the experienced workforce. The model specification can also examine whether changes in the return to education (i.e., for the population in general) affect recent immigrants' earning gap.

The analysis is conducted separately for three time periods, 1980-1990, 1990-2000, and 20002005. The starting and end points in these periods were in similar positions in the business cycle. Thus, the impact of business cycle on immigrants' entry earnings gap is by and large removed in the analysis. Examining the three periods separately allows us to test the possibility that the determinants of the increasing entry earnings gap changed over time.

\section{Data and methods}

\section{Data and variables}

The present study uses the 20 per cent sample micro-data files from the 1981, 1991, 2001, and 2006 censuses of Canada. The study population contains individuals who were aged 25 to 59 and had positive annual employment income, and who worked at least one week in the calendar year before the census. The analysis includes only the Canadian-born and recent immigrants, and excludes more established immigrants, since the study focus is on changes in the immigrant entry earnings gap. Recent immigrants are defined as those who were landed immigrants in Canada for five full years or less at the time of the census, e.g., those landed from 1975 to 1979 in the 1981 census, and those landed from 2000 to 2004 in the 2006 census. Those who landed in the year prior to the census were not included, as most of them had not stayed a full year in Canada.

The analysis further restricts the recent immigrant sample to those whose age at immigration was 25 to 59. Immigrants who arrive at a younger age are often the dependents of working-age immigrants or international students. They are likely to have received some of their education in Canada, and have earnings profiles similar to the Canadian-born (Schaafsma and Sweetman 2001).

The outcome variable is log weekly earnings (annual earnings divided by weeks worked). ${ }^{2}$ Explanatory variables include education, potential years of Canadian and foreign work experience (separately), marital status, full-time/part-time status, visible minority status, location of residence, and immigrant composition in language and source regions. Education is grouped into five categories: no high school certificate, high school certificate or diploma, non-university certificate or diploma, Bachelor's degree, and graduate degree. With the exception of the 2006 census, it is not possible to identify whether immigrants received their highest levels of education in Canada or abroad. Instead of trying to separate Canadian education from foreign education, recent immigrants and the Canadian-born are allowed to have different returns to education in all models.

2 This study compared the results based on log weekly earnings versus log annual earnings. The earnings gap between recent immigrants and the Canadian-born was larger and expanded more in log annual earnings than in log weekly earnings. This is because recent immigrants tended to work fewer weeks and more parttime than the Canadian-born, and these differences in working time also increased over time. However, after adjusting for weeks worked and other variables, the trend in the adjusted annual earnings gap was similar to that in the adjusted weekly earnings. 
In the analysis, potential Canadian work experience is distinguished from foreign work experience for recent immigrants. For the Canadian-born, all their potential years of experience are assumed to have been acquired in Canada, and are estimated as "age minus years of schooling and minus 6." For recent immigrants, foreign experience is derived as "age at immigration minus years of schooling and minus 6" if the value is positive or 0. Their Canadian work experience is simply the difference between their total potential years of experience and the estimated years of foreign experience. The models allow recent immigrants and the Canadian-born to have different returns to Canadian experience.

Marital status is coded as a dummy variable: married vs. others. Visible minority status is coded as visible minorities vs. non-visible minorities. Place of residence is grouped into 14 categories: Montréal, Toronto, Vancouver, the ten provinces (excluding the three largest metropolitan areas in their respective province), and the territories.

Immigrant language is coded as six categories, based on the combination of mother tongue and self-reported official language: mother tongue is English, mother tongue is French, mother tongue is non-English/French but speaks English, mother tongue is non-English/French but speaks French, mother tongue is non-English/French but speaks both English and French, mother tongue is nonEnglish/French and does not speak English or French. The country of birth is coded into 43 groups to distinguish the major immigrant source regions. ${ }^{4}$

\section{Methods: inter-temporal decomposition of changes in earnings gaps}

To evaluate the relative contributions of various factors to the change in the earnings gap for recent immigrants, the conventional approach is to pool the data for non-immigrants and immigrants from different time periods (e.g., Aydemir and Skuterud 2005). A baseline regression model is constructed to include a dummy variable for immigrant status, a series of dummies for immigrant arriving cohorts, years since immigration, the interaction terms between cohorts and year since immigration. Subsequent models are then constructed to add explanatory variables, which are typically added one at a time in order to assess their effect on the entry earnings gap. The reduction in the coefficients on immigrant cohort dummies between the baseline model and subsequent models is interpreted as the "explained" portion of the changes in the entry earnings gap accounted for by the added explanatory variables.

One potential problem with this approach is that the order of adding the potential explanatory variables into the model matters. If there are overlapping effects among these explanatory variables, the relative importance of a variable depends on whether it enters the model before or after other variables.

To overcome this problem, an inter-temporal decomposition approach is developed. This approach takes into account overlapping effects among explanatory variables. All explanatory variables are included simultaneously in the model, and then the relative contribution of each variable is calcu-

\footnotetext{
3 Most people started formal schooling at age 6 . The potential years of work experience are estimated as the difference between current age and years from birth to the end of formal schooling.

4 They are USA, Haiti, Jamaica, Trinidad, Other Caribbean, Central America, Guyana, Other South America, UK, Netherlands, France, Germany, Italy, Portugal, Other Northern/Western/Southern Europe, Former Yugoslavia, Poland, Former USSR, Other Eastern Europe, Israel, Lebanon, Iran, Egypt, Other West Asia/ Middle East, China, Hong Kong, Taiwan, Korea, Other Eastern Asia, Philippines, Vietnam, Other Southeast Asia, India, Pakistan/Bangladesh, Other South Asia, Northern Africa, Western/Central Africa, Southern Africa ,Eastern Africa, Kenya, Australia, New Zealand, and Other countries.
} 
lated. This is equivalent to the Oaxaca decomposition, with four separate regression models, each for one group at one time point, and using the regression coefficients from the pooled sample as the weights to compute the contribution of differences in population characteristics. This approach is outlined below.

For each time period, data on recent immigrants and the Canadian-born from two censuses are pooled to estimate the following models:

Base Model

$$
\mathrm{Y}=\mathrm{a}^{\dagger}+\beta_{1}^{\dagger *} \mathrm{~T}+\beta_{2}^{\dagger *} \mathrm{IM}+\beta_{3}^{\dagger *} \mathrm{IM} * \mathrm{~T},
$$

where $\mathrm{Y}$ is log weekly earnings, $\mathrm{T}$ is a dummy variable for census income year (the later year $=1$ ), and IM is a dummy variable for immigrant status (recent immigrant $=1$, the Canadian-born $=0$ ).

This model simply replicates the average earnings gap between recent immigrants and the Canadian-born observed in the raw data. In this specification, $\mathrm{a}^{\dagger}$ is the average log weekly earnings of the Canadian-born in the first year of the period (year 1), $\beta_{1}^{\dagger}$ is the change in earnings among the Canadian-born between year 1 and the final year of the period (year 2). $\beta_{2}^{\dagger}$ is the earnings gap between recent immigrants and the Canadian-born in year 1 , while $\beta_{2}{ }^{\dagger}+\beta_{3}{ }^{\dagger}$ is the earnings gap between recent immigrants and the Canadian-born in year 2 . Thus, $\beta_{3}^{\dagger}$ is the change over the period in the earnings gap between recent immigrants and the Canadian-born. Model 1 adds several sets of control variables to the base model.

$$
\mathrm{Y}=\mathrm{a}+\beta_{1} * \mathrm{~T}+\beta_{2} * \mathrm{IM}+\beta_{3} * \mathrm{IM} * \mathrm{~T}+\beta_{\mathrm{x}} * \mathrm{X}+\beta_{\mathrm{z}} * \mathrm{Z} * \mathrm{IM}+\beta_{\mathrm{si}} * \mathrm{~S} * \mathrm{IM}+\beta_{\mathrm{st}} * \mathrm{~S} * \mathrm{~T},
$$

where $\mathrm{X}$ are variables applicable to both the Canadian-born and recent immigrants, including education, years of potential Canadian experience, location, marital status, fulltime/part time status, and visible minority status. $Z$ represents variables specific to recent immigrants, including language and country of birth. S represents two skill variables_education and Canadian experience (both are part of $\mathrm{X}$ variables). The interaction term $\mathrm{S}^{*} \mathrm{IM}$ allows recent immigrants and the Canadian-born to have different returns to education and Canadian experience. The term $\mathrm{S}^{*} \mathrm{~T}$ is used to capture changes in returns to education and Canadian experience for the general population (i.e., immigrants and the Canadian-born combined). Since $T=0$ for the initial year, and 1 for the final year, $\beta_{\text {st }}$ (one set for education* $\mathrm{T}$ and one set for experience*T) represent the change in returns to education and Canadian experience over the study period of interest.

In Model $1, \beta_{2}$ is the earnings gap between recent immigrants and the Canadian-born in year 1 , controlling for other variables in the model, while $\beta_{2}+\beta_{3}$ is the earnings gap between recent immigrants and the Canadian-born in year 2 , with controls. Thus, $\beta_{3}$ is the change in earnings gap between recent immigrants and the Canadian-born, with controls.

The difference between $\beta_{3}{ }^{\dagger}$ in the base model and $\beta_{3}$ in Model 1 is the portion of the change in the earnings gap that is accounted for by the included control variables - the "explained" component in the conventional Oaxaca decomposition. The "explained" changes in the earnings gap can be further decomposed using the following equation:

$$
\beta_{3}^{\dagger}-\beta_{3}=\beta_{\mathrm{st}} * \Delta \mathrm{S}_{\mathrm{t} 2}+\beta_{\mathrm{x}}^{*}\left(\Delta \mathrm{X}_{\mathrm{t} 2}-\Delta \mathrm{X}_{\mathrm{t} 1}\right)+\beta_{\mathrm{si}} * \Delta \mathrm{S}_{\mathrm{im}}+\beta_{\mathrm{z}}^{*} \Delta \mathrm{Z}
$$

where $\Delta \mathrm{S}_{\mathrm{t} 2}$ are differences in skill levels (education and Canadian experience) between immigrants and the Canadian-born at time $2, \Delta \mathrm{X}_{\mathrm{t} 1}$ are differences in characteristics between recent immigrants and the Canadian-born at time 1 , and $\Delta \mathrm{X}_{\mathrm{t} 2}$ are differences in characteristics between recent im- 
migrants and the Canadian-born at time $2, \Delta \mathrm{S}_{\mathrm{im}}$ are changes in skill levels (education and Canadian experience) among recent immigrants between time 1 and time 2 , and $\Delta \mathrm{Z}$ are changes in immigrantspecific characteristics between time 1 and time 2 .

This approach in essence ascribes the change in the earnings gap that is accounted for by the controls (i.e., the "explained" component, as measured by $\beta_{3}^{\dagger}-\beta_{3}$ ) to two main components. The first, $\beta_{\mathrm{st}} * \Delta \mathrm{S}_{\mathrm{t} 2}$, reflects the effects of changes in returns to skills, including the changes in returns to education and Canadian experience (for immigrants and the Canadian-born combined).

The second component captures the effects of changes in population characteristics. This component can be further split into two groups. One reflects the effects of changing characteristics applicable to both the Canadian-born and to immigrants, $\beta_{\mathrm{x}} *\left(\Delta \mathrm{X}_{\mathrm{t} 2}-\Delta \mathrm{X}_{\mathrm{t} 1}\right)+\beta_{\mathrm{si}} * \Delta \mathrm{S}_{\mathrm{im}}$. These characteristics include education, Canadian experience, full time/part time status, geographic location, marital status, and racial minority status. The other group, $\beta_{\mathrm{z}}{ }^{*} \Delta \mathrm{Z}$, reflects the effects of changes in immigrant-specific characteristics, which include foreign experience, language, and source region.

From this equation, it is straightforward to compute the contribution of each set of variables to the "explained" component. For instance, the relative contribution of changes in immigrant-specific characteristics is $\left(\beta_{\mathrm{z}}{ }^{*} \Delta \mathrm{Z}\right) /\left(\beta_{3}^{\dagger}-\beta_{3}\right)$. The contribution of each individual variable to the "explained" component can also be computed. For instance, the relative contribution from the changes in the distribution of source region $(\Delta \mathrm{SR})$ is $\left(\beta_{\mathrm{sr}} * \Delta \mathrm{SR}\right) /\left(\beta_{3}^{\dagger}-\beta_{3}\right)$.

Building on Model 1, we can add three-way interaction terms (i.e., among IM, T, and an immigrant-specific variable) in a subsequent Model 2 to include changes in returns to foreign experience and immigrant education.

$$
\begin{aligned}
\mathrm{Y}= & \mathrm{a}+\beta^{\prime}{ }_{1} * \mathrm{~T}+\beta^{\prime}{ }^{*} * \mathrm{IM}+\beta_{3}^{\prime} * \mathrm{IM}_{3} * \mathrm{~T}+\beta_{\mathrm{x}} * \mathrm{X}+\beta_{\mathrm{z}} * \mathrm{Z} * \mathrm{IM}+\beta_{\mathrm{si}} * \mathrm{~S} * \mathrm{IM}+\beta_{\mathrm{st}} * \mathrm{~S} * \\
& \mathrm{~T}+\beta_{\mathrm{tf}}^{\prime} * \mathrm{IM} * \mathrm{~T}^{2} * \mathrm{Fexp}+\beta_{\mathrm{tei}}^{\prime}{ }^{*} \mathrm{IM} * \mathrm{~T}^{*} \mathrm{EDU}
\end{aligned}
$$

Model 2 allows us to detect any changes in returns to these two variables among recent immigrants over time.

Ideally, we would develop a decomposition based on Model 2 to determine the extent to which changes (if any) in the returns to foreign experience and immigrant education influence the entry earnings gap. However, as noted by Oaxaca and Ransom (1999), this cannot be reliably done. Changing returns to immigrant-specific factors such as foreign experience are part of the "unexplained" portion of the change in earnings gap, i.e., the effect on the earnings gap of the $\beta$ that are specific to one group..$^{5}$ It is problematic to quantify the individual contribution of change in $\beta_{\mathrm{s}}$ that is specific to immigrants to the "unexplained" portion.

Earlier studies have attempted to assess the role of changing returns to foreign experience on changes in immigrant earnings. Aydemir and Skuterud (2005) estimated whether there were significant changes in the returns to foreign experience by entering the three-way interaction just as in Model 2. They went further and measured the share of the decline in entry earnings attributable to changing returns to immigrant-specific characteristics. They conclude that changing returns to foreign experience play a large role in influencing the immigrant earnings gap, based on the observation that the three-way interaction is significant and $\beta_{3}^{\prime}$ in Model 2 is substantially smaller than $\beta_{3}$ in Model 1 . But when the change in the return to foreign experience (i.e., the three-way interaction IM* $\mathrm{T}^{*} \mathrm{Fexp}$ )

5 Note that the inter-temporal decomposition can capture the effect on the earnings gap of changes in $\beta_{\text {st }}$ that apply to both immigrants and the Canadian-born, e.g., returns to Canadian experience and returns to education for the population as a whole. Both are two-way interaction terms (e.g., EXP*T). Changes in returns to foreign experience, which is a three-way interaction term $\left(\mathrm{IM}^{*} \mathrm{Fexp} * \mathrm{~T}\right)$, however, apply only to immigrants. 
is included in the model, $\beta_{3}^{\prime}$, the coefficient for IM*T, has to be interpreted in conjunction with $\beta^{2}{ }^{*} \mathrm{IM}^{*} \mathrm{~T}$ *Fexp because the three-way interaction also contains the two-way interaction IM*T. Thus, the change in earnings gap as a result of allowing the change in returns to foreign experience is not the difference between $\beta_{3}$ and $\beta^{\prime}$, but rather the difference between $\beta_{3}$ and $\beta^{\prime}{ }_{3}+\beta^{\prime}{ }_{\text {tf }}^{*}$ Fexp. The latter term is not constant and varies with the value of Fexp (years of foreign experience).

\section{Results}

\section{Compositional changes among recent immigrants and the Canadian-born}

Changes in demographic composition among both recent immigrants and the Canadian-born are a potential determinant of the trend in their earnings gaps. Table 1 presents changes in selected socio-demographic variables over the past quarter-century for male earners included in the study (the table for female earners is available upon request).

As shown in Table 1, the relative educational advantage of recent immigrants (over the Canadianborn) narrowed slightly in the 1980s, but expanded substantially since. Twenty-seven per cent of male recent immigrants had a Bachelor's or graduate degree in 1980, twice that of the Canadian-born (13.6 per cent). This ratio was reduced to about 1.8 (28.8 per cent vs. 15.9 per cent) in 1990 . This is consistent with Reitz's observation that increases in education among recent immigrants did not keep pace with the increase among the Canadian-born in this period (Reitz 2001). However, the educational level among new immigrants increased rapidly following the early1990s, when Canada altered its immigrant selection criteria. By 2005, the percentage of recent immigrant men with a Bachelor's or graduate degree (61.3 per cent) was three times as high as that among the Canadian-born (20.1 per cent). Similar trends are observed among female earners.

The shift in source regions and in official language ability occurred primarily in the 1980s. In the 1990s and early 2000s, further compositional changes were observed mostly among non-traditional source countries. Recent immigrants were much more likely to be visible minorities than were the

Table 1. Compositional changes among the Canadian born and recent immigrant male earners.

\begin{tabular}{|c|c|c|c|c|c|c|c|c|}
\hline & \multicolumn{4}{|c|}{ Canadian born } & \multicolumn{4}{|c|}{ Recent immigrants } \\
\hline & 1980 & 1990 & 2000 & 2005 & 1980 & 1990 & 2000 & 2005 \\
\hline \% with Bachelor's degree & 8.7 & 10.5 & 12.7 & 13.6 & 13.6 & 14.4 & 24.3 & 31.4 \\
\hline$\%$ with graduate degree & 4.9 & 5.4 & 6.1 & 6.5 & 13.6 & 14.1 & 25.4 & 29.9 \\
\hline Years of Canadian experience & 20.7 & 19.7 & 21.3 & 21.9 & 3.3 & 2.5 & 3.0 & 3.1 \\
\hline Years of foreign experience & - & - & - & - & 13.9 & 14.7 & 14.7 & 13.8 \\
\hline$\%$ visible minorities & 0.6 & 1.2 & 1.7 & 2.5 & 50.4 & 66.8 & 70.3 & 73.8 \\
\hline$\%$ English/French mother tongue & - & - & - & - & 47.6 & 25.0 & 19.8 & 18.6 \\
\hline \multicolumn{9}{|l|}{ Source country/region $(\%)$} \\
\hline USA & - & - & - & - & 6.5 & 2.8 & 1.6 & 1.7 \\
\hline Latin America & - & - & - & - & 14.7 & 14.7 & 8.6 & 9.6 \\
\hline Europe & - & - & - & - & 37.3 & 27.2 & 23.3 & 18.7 \\
\hline Eastern Asia & - & - & - & - & 10.0 & 16.0 & 21.4 & 20.0 \\
\hline Southeast Asia & - & - & - & - & 11.2 & 12.0 & 8.5 & 8.0 \\
\hline South Asia & - & - & - & - & 7.3 & 10.4 & 19.4 & 23.0 \\
\hline West Asia/Middle East & - & - & - & - & 4.8 & 8.6 & 8.8 & 7.3 \\
\hline Africa & - & - & - & - & 6.1 & 7.5 & 7.7 & 11.0 \\
\hline Oceania and other countries & - & - & - & - & 2.1 & 0.8 & 0.7 & 0.9 \\
\hline Number of observations & 742,590 & 917,460 & 955,870 & 979,180 & 16,990 & 22,650 & 31,360 & 39,040 \\
\hline
\end{tabular}

Note: The numbers of observations are rounded to the nearest 10.

Source: the 1981, 1991, 2001 and 2006 Canadian census 20\% sample micro-data files. 
Hou: Immigrant entry earnings over the past quarter-century

Table 2. Average log weekly earnings of the Canadian-born and recent immigrant earners aged 25 to 59, 1980-2005.

\begin{tabular}{lrrrr}
\hline & 1980 & 1990 & 2000 & 2005 \\
\hline Men & & & & \\
Canadian born & 6.80 & 6.73 & 6.71 & 6.74 \\
Recent immigrants & 6.69 & 6.44 & 6.43 & 6.41 \\
Gap & -0.11 & -0.29 & -0.28 & -0.33 \\
Women & & & & \\
$\quad$ Canadian born & 6.18 & 6.22 & 6.29 & 6.36 \\
Recent immigrants & 6.06 & 6.06 & 6.04 & 6.05 \\
Gap & -0.11 & -0.16 & -0.25 & -0.30 \\
\hline
\end{tabular}

Source: 1981, 1991, 2001 and 2006 Canadian census 20\% sample microdata files.

Canadian-born. While the share of the Canadian-born who were visible minorities rose continuously, it remained trivial compared with that among recent immigrants.

\section{Trends in weekly earnings among recent immigrants and the Canadian-born}

Among male earners, the gap in weekly earnings between the Canadian-born and recent immigrants expanded the most during the 1980s (Table 2). Between 1980 and 1990, log weekly earnings decreased 0.07 among the Canadian-born, or an approximately a 7 -percentage-point decrease, ${ }^{6}$ but approximately 25 percentage points among male recent immigrants. As a consequence, the Canadianborn - immigrant entry earnings gap widened 18 percentage points.

In the 1990s, the earnings gap changed little as Canadian-born and recent-immigrant men experienced similar small declines. In the early 2000s, the earnings gap expanded again as earnings grew among the Canadian-born but declined among entering recent immigrants. By 2005, the earnings gap between recent-immigrant and Canadian-born men grew to 33 percentage points.

The earnings gap between recent-immigrant and Canadian-born women expanded throughout the past quarter-century, although more so in the 1990s. Unlike recent immigrant men, whose earnings declined in absolute values, immigrant women experienced little long-term changes in earnings. However, the earnings of Canadian-born women improved steadily, and hence the Canadian-immigrant entry earnings gap increased, reaching 30 percentage points by 2005 .

\section{The impact of compositional shifts and changing returns to skills}

To examine the extent that the changing earnings gap for recent immigrants is associated with compositional shifts and changes in returns to skills, regression models were constructed as specified in the Base Model and Model 1 (tables for these models are available on request), and decompositions were performed as outlined in the Data and Methods section. The results are summarized in Table 3.

Among men, compositional shifts accounted for most of the rising earnings gap for recentimmigrant men in 1980s. Of the total "explained" change in the earnings gap (-.171), close to 82 per cent was attributable to changes in the characteristics of immigrants and the Canadian-born. Shifts in immigrant language and source regions alone accounted for 41 per cent of the "explained" component $(-.070 /-.171)$. The other important compositional changes were a slower growth in

6 The difference in log earnings (when times 100) can be interpreted as approximate percentage differences in actual earnings. Large log differences (especially those in absolute value larger than 0.10 ) often overestimate the percentage difference. 
Table 3. The contribution of skill-biased labour market changes and compositional shifts to the changes in the earnings gap between recent immigrants and Canadian-born workers aged 25 to 59.

\begin{tabular}{|c|c|c|c|c|c|c|}
\hline & \multicolumn{3}{|c|}{ Men } & \multicolumn{3}{|c|}{ Women } \\
\hline & $1980-1990$ & $1990-2000$ & $2000-2005$ & 1980-1990 & $1990-2000$ & $2000-2005$ \\
\hline Change in gaps & -0.182 & 0.008 & -0.051 & -0.044 & -0.092 & -0.054 \\
\hline "Unexplained" component & -0.010 & -0.015 & -0.056 & 0.065 & 0.010 & 0.016 \\
\hline "Explained" component & -0.171 & 0.023 & 0.005 & -0.109 & -0.102 & -0.071 \\
\hline Due to changes in returns to skills & -0.031 & 0.023 & -0.011 & -0.037 & -0.050 & -0.032 \\
\hline $\begin{array}{l}\text { Changes in return to Canadian } \\
\text { experience }\end{array}$ & -0.037 & -0.001 & 0.016 & -0.041 & -0.061 & -0.031 \\
\hline Changes in return to education & 0.006 & 0.024 & -0.027 & 0.004 & 0.010 & -0.001 \\
\hline Due to changes in characteristics & -0.141 & 0.000 & 0.016 & -0.072 & -0.051 & -0.039 \\
\hline $\begin{array}{l}\text { Immigrant-Canadian born } \\
\text { difference in education }\end{array}$ & -0.024 & 0.042 & 0.017 & -0.028 & 0.003 & 0.002 \\
\hline $\begin{array}{l}\text { Immigrant-Canadian born } \\
\text { difference in Canadian experience }\end{array}$ & -0.033 & -0.002 & 0.000 & -0.033 & 0.008 & -0.005 \\
\hline Working full time & -0.011 & -0.015 & 0.004 & -0.007 & -0.040 & -0.023 \\
\hline Location + Marital status & 0.008 & 0.015 & -0.005 & 0.015 & 0.005 & -0.007 \\
\hline Racial minority status & -0.010 & -0.002 & -0.002 & -0.001 & 0.000 & -0.001 \\
\hline Foreign experience & -0.001 & 0.001 & 0.005 & 0.001 & 0.004 & 0.005 \\
\hline Mother tongue & -0.014 & 0.000 & -0.002 & -0.010 & -0.002 & -0.001 \\
\hline Source region & -0.056 & -0.040 & -0.001 & -0.010 & -0.028 & -0.010 \\
\hline
\end{tabular}

Source: authors' model estimates based on the 1981, 1991, 2001 and 2006 Canadian census 20\% sample micro-data files.

education and a larger decrease in years of Canadian experience among recent immigrants relative to the Canadian-born, contributing to 33 per cent (-.057) of the "explained" component. Changes in the return to Canadian experience and education were associated with about 18 per cent of the "explained" change in the earnings gap.

In the 1990s, changes in population characteristics contributed little to the trend in the earnings gap for recent-immigrant men. While shifts in recent immigrant source regions tended to increase the earnings gap, rapidly rising education tended to reduce the gap. These two effects offset each other. Changes in the returns to skills tended to reduce the earnings gap for recent-immigrant men because of rising returns to education and a faster rise in education among recent immigrants than among the Canadian-born.

In the early 2000s, the combined effects of changing returns to skills and compositional shifts accounted for little of the rise in the earning gap for recent-immigrant men. While changes in population characteristics tended to reduce the gap slightly, this effect was mostly offset by that of changing returns to skills.

Overall, the "unexplained" portion of the change in weekly earnings gaps, after accounting for the effects of the explanatory variables in Model 1, were small among men in the 1980s and 1990s $(-.010$ and -.015 respectively), but grew to -.056 in the early 2000 s (Table 3$)$.

Among women, changes in returns to skills and compositional shifts accounted for all the expansion in the earnings gap in the three time periods. While the effect of change in population characteristics decreased over time, the effect of changes in returns to skills was rather consistent over the three periods. Hence, during the 1980s, compositional changes accounted for the majority of the increase in immigrant women's earnings gap. By the early 2000s, the effect of compositional shifts and changes in returns to skills were roughly equal. 
Hou: Immigrant entry earnings over the past quarter-century

\section{The impact of the IT boom and bust in the early 2000s}

The expansion of earnings gaps for recent-immigrant men in the early 2000s was not accounted for by compositional shifts and changes in returns to skills. Other changes in the labour market, particularly the demand/supply shifts, could have played a role. Picot and Hou (2009) found that the downturn in the information technology (IT) sector after 2000 negatively affected the entry earnings of recent immigrants. Employment in the IT sector in Canada declined 6 per cent from 2001 to 2005 (based on Labour Force Survey). However, the annual inflows of skilled economic immigrants who intended to work as IT or engineering professionals increased from about 2,000 in 1990 to a peak of 25,000 in 2001, and then gradually decreased to about 19,000 by 2005 (Picot and Hou 2009). At a time when IT employment was contracting, the supply of IT workers via immigration was at historical high. Based on data compiled from immigrant landing records and tax files, Picot and Hou (2009) showed that the decline in immigrant entry earnings was almost entirely concentrated among immigrant IT professionals and engineers. However, Picot and Hou (2009) could not examine changes in earnings gaps between recent immigrants and the Canadian-born, since their data contain no information on education and occupation for the Canadian-born.

The present study complements the study by Picot and Hou (2009) by examining the impact of IT employment fluctuations on earnings gaps between recent immigrants and the Canadian-born with census data. The census allows us to make conditional comparisons (conditional on education in particular), and contains information on actual occupations, rather than intended occupations as used in the study by Picot and Hou (2009), for both immigrants and the Canadian-born.

The IT boom and bust could affect the relative entry earnings of immigrants through changes in the proportions employed in the IT sector and the earnings of IT workers. As shown in Table 4, between 1990 and 2000, when the demand for IT workers rose dramatically, the proportion of recent immigrants working in IT occupations increased much faster than that of the Canadian-born. By 2000, about 14 per cent recent-immigrant men were IT workers, compared with only 4 per cent of Canadian-born men. In contrast, between 2000 and 2005, when the demand for IT workers decreased, employment in the IT sector continued to rise among the Canadian-born but decreased among recent immigrants, particularly among immigrant women. Accordingly, the proportion of IT workers decreased among recent immigrants, while increasing slightly among Canadian-born men.

Furthermore, changes in the demand for IT workers also affected the relative earnings of recentimmigrant IT workers. At the peak in 2000, male recent-immigrant IT workers earned almost the same weekly wages as their Canadian-born counterparts (Table 5). When the demand was reduced 5

Table 4. The numbers and shares of IT workers among Canadianborn and recent immigrant workers.

\begin{tabular}{rrrrrrr}
\hline & \multicolumn{2}{c}{ Numbers of IT workers } & & \multicolumn{2}{c}{ Shares of IT workers } \\
\cline { 6 - 6 } \cline { 5 - 6 } & $\begin{array}{c}\text { Canadian } \\
\text { born }\end{array}$ & $\begin{array}{c}\text { Recent } \\
\text { immigrants }\end{array}$ & & $\begin{array}{c}\text { Canadian } \\
\text { born }\end{array}$ & $\begin{array}{c}\text { Recent } \\
\text { immigrants }\end{array}$ \\
\cline { 1 - 1 } \cline { 5 - 6 } Men & & & & & \\
1990 & 97,290 & 4,130 & & $2.2 \%$ & $3.5 \%$ \\
2000 & 190,790 & 23,780 & & $4.1 \%$ & $14.4 \%$ \\
2005 & 216,960 & 23,490 & & $4.5 \%$ & $11.7 \%$ \\
Women & & & & & \\
1990 & 44,790 & 1,650 & & $1.2 \%$ & $1.7 \%$ \\
2000 & 75,460 & 8,230 & & $1.7 \%$ & $6.0 \%$ \\
2005 & 76,830 & 6,240 & & $1.7 \%$ & $3.6 \%$ \\
\hline
\end{tabular}

Note: The numbers of estimated IT workers are rounded to the nearest 10 . Source: the 1991, 2001 and 2006 Canadian census 20\% sample micro-data files. 
Table 5. Changes in weekly wages of IT and other workers by immigration status (in 2005 constant \$).

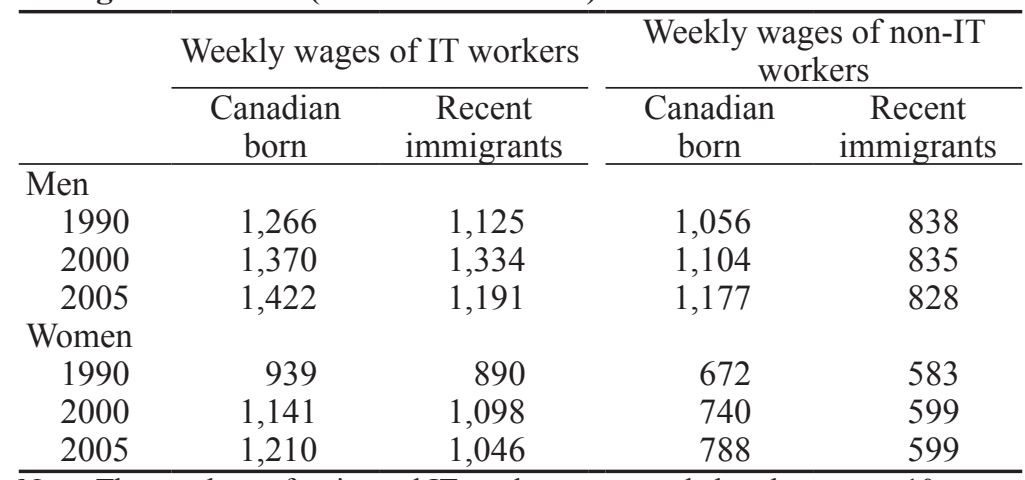

Note: The numbers of estimated IT workers are rounded to the nearest 10.

Source: the 1991, 2001 and 2006 Canadian census 20\% sample micro-data files

years later, male recent-immigrant IT workers earned 16 per cent less than the Canadian-born. This is a remarkable change within a rather short period of time.

Since IT workers earned more than non-IT workers, the larger gain in the proportion working in the IT sector, and the high earnings of IT workers among recent immigrants, tended to improve their overall entry earnings relative to the Canadian-born during the period of the IT boom in the 1990s. The opposite occurred during the period of the IT bust. As a result, the IT fluctuation had a large impact on changes in the relative entry earnings of immigrants in both the 1990s and early 2000s. As shown in Table 6, in the 1990s, the relative entry earnings of immigrants remained stable without controls, and expanded by 1.5 percentage points with controls for compositional shifts and changes in returns to skills. Excluding IT workers, however, the entry earnings gap expanded 5.9 percentage points without controls, and 4.8 percentage points with controls. Among non-IT workers there was an increase in the entry earnings gap during the 1990s.

In contrast, in the early 2000s, the entry earnings gap among male workers expanded 5.1 percentage points without controls and 5.6 percentage points with controls. This expansion was concentrated among IT workers, whose earnings gap increased 14.9 per cent without controls and 9.9 per cent with controls (Table 6). Among non-IT workers there was relatively little increase in the gap. Similarly, recent female-immigrant IT workers experienced a large expansion in their earnings gap with the Canadian-born.

Table 6. Impact of the IT boom and downturn on the earnings gaps of recent immigrants.

\begin{tabular}{|c|c|c|c|c|}
\hline & \multicolumn{4}{|c|}{ Change in earnings gaps with the Canadian born } \\
\hline & \multicolumn{2}{|c|}{$1990-2000$} & \multicolumn{2}{|c|}{$2000-2005$} \\
\hline & Observed & $\begin{array}{c}\text { With } \\
\text { controls }\end{array}$ & Observed & $\begin{array}{c}\text { With } \\
\text { controls }\end{array}$ \\
\hline \multicolumn{5}{|l|}{ Men } \\
\hline All recent immigrants & 0.008 & -0.015 & -0.051 & -0.056 \\
\hline Non IT workers & -0.059 & -0.048 & -0.017 & -0.025 \\
\hline IT workers & 0.096 & 0.058 & -0.149 & -0.099 \\
\hline \multicolumn{5}{|l|}{ Women } \\
\hline All recent immigrants & -0.092 & 0.010 & -0.054 & 0.016 \\
\hline Non IT workers & -0.127 & -0.004 & -0.030 & 0.039 \\
\hline IT workers & 0.022 & 0.134 & -0.176 & -0.073 \\
\hline
\end{tabular}


Hou: Immigrant entry earnings over the past quarter-century

\section{Conclusions}

This paper examines the factors associated with the rise in the entry earnings gap of recent immigrants relative to the Canadian-born, and the changing effects of these factors over the 1980s, 1990s, and early 2000s. This longer perspective leads to conclusions that differ from the earlier work in some important aspects.

First, changes in population characteristics were the dominant factor affecting the immigrant entry earnings gap during the 1980s. Of the three decades, the 1980s witnessed the largest increase in the unadjusted earnings gap for immigrant men, driven largely by a significant shift in source regions. The effect of such "compositional" shifts became trivial in the 1990s as rapidly rising education and continuing shift in immigrant source regions offset each other's effects. In the early 2000s, the effect of compositional shifts on the gap was reversed; they tended to reduce the gap. For women, like men, the effect of compositional shifts was greatest during the 1980s, and then fell continuously through the 1990s and early 2000s.

Second, the effect of changing returns to Canadian experience and education on immigrant entry earnings gap was generally small for immigrant men, particularly in the 1990s and early 2000s, but was stronger for immigrant women in all three periods. Rapidly rising returns to education, which was observed among both entering immigrants and the Canadian-born over the 1990s, was actually in favor of immigrants. This is because the educational attainment of entering immigrants was rising much faster than that of the Canadian-born in the 1990s, and as a result recent immigrants benefited more from the rising relative returns. For female immigrants, the effect of changing returns to education on their entry earnings gap was generally small, since education also increased fast among the Canadian-born women.

Rising returns to Canadian experience accounted for about one-fifth of the expansion in the recent-immigrant men's earnings gap in the 1980s, but the effect became trivial in the 1990s and tended to reduce immigrant men's earning gap in the early 2000s. For recent-immigrant women, the large rise in the returns to Canadian experience was among the most important factors contributing to their widening earnings gap throughout the whole study period. This large increase in the returns to Canadian experience of course benefited the Canadian-born more than entering immigrants, since immigrants have much less Canadian experience.

Third, the study shows that changes in labour supply-demand can affect recent immigrants severally. This is exemplified by the impact of employment fluctuation in the IT sector. At the peak of the IT boom, immigrant IT workers earned almost the same as Canadian-born IT workers. During the IT bust from 2000 to 2005; however, the earnings of IT workers declined considerably among immigrants but continued to increase among the Canadian-born. Consequently, the earnings gap widened significantly between recent-immigrant and Canadian-born IT workers. The IT bust, combined with a large concentration of entering immigrants in this sector, was the major explanation for the rise in the entry earnings gap of recent immigrants in the early 2000s. The effect of falling labour demand in the IT sector likely spilled over into other sectors, since many recent immigrants trained as IT professionals had to find jobs in other sectors. The IT downturn was also likely the primary reason for the large decline in the relative return to higher education among entering immigrants in this period, because recent immigrants trained as IT professionals were mostly university graduates.

This study's results about the changing effects of major explanatory factors over three distinct periods suggest that the immigrant entry earnings gap is unlikely to expand in the near future, at least not at the pace observed in the 1980s and the early 2000s. The largest increase in the gap was observed during the 1980s, driven largely by shifts in source regions. The shifts in immigrant source regions and language ability stabilized by the early 2000s and may not negatively affect future trends in immigrants' earnings gap, barring some possible significant change in immigration patterns (e.g., 
it may become less easy to attract highly educated immigrants from fast-growing Asian economies). Changes in returns to Canadian experience and education played a moderate role in the 1980s, but the effect has become small, at least for the earnings gap of recent-immigrant men. The reason for the expanding earnings gap in the early 2000s was unique. The downturn of a single industrial sector (IT) affected a substantial share of recent immigrants. A similar event may not be repeated, although the recent 2008-09 recession would have some negative effects on immigrants' relative earnings.

The findings of this study have two important policy implications. First, further fine-tuning in immigration selection policies, aimed at altering immigrant characteristics, would certainly help reduce the immigrant entry earnings gap, but the effect is likely limited. From 1990 to 2005, changes in selection regulations doubled the share of university-educated immigrants from 29 to 61 per cent. This drastic rise in educational attainment merely offsets the negative effect of continuing shifts in source regions on entry earnings in the 1990s. While resource region composition has mostly stabilized, there is not much room for further increase in education levels, since only about one-quarter of all immigrants, i.e., the principal applicants of the economic class, are subject to the selection criteria. The formal testing of official language proficiency introduced recently (rather than the previously reliance on immigrant self-reporting and casual evaluation by immigration officers) would improve immigrants' language competency levels. However, its impact on the future trend of the immigrant entry earnings gap is uncertain, since changes in language composition, independent of changes in source countries and education, have had a small effect on the past trend of the entry earnings gap.

Second, the impact of the IT boom and bust on immigrant entry earnings indicates that a closer match between immigration level and labour demand would go a long way towards improving immigrants' entry earnings. Foreign-acquired skills and difficulties with official language(s) did not deter recent immigrants from finding jobs and getting paid as well as the Canadian-born in occupations with a strong demand for labour. When demand was weak, however, even a subtle difference (e.g., an accent) would become a major stumbling block. The results also suggest that it is not necessary, and not practical, to deliberately match immigrant supply and labour demand for specific industrial or occupational niches - a practice that had been implemented from the 1970s to the early 1990s and proved to be ineffective because of the difficulties of forecasting labour demand for specific industrial sectors or occupations (Green and Green 1999). The large increase in the number of immigrants who intended to work as IT professionals in the late 1990s, at the time when no designated occupations were included in the selection criteria, suggests that immigration can rapidly fill short-term occupational demand gaps even without governments' deliberate efforts to monitor demand or specify recruitment targets for specific occupations. The problem is to reduce inflows when the demand is weakening. This can be more easily done by linking the annual intake of all immigrants with current macroeconomic conditions, particularly the national unemployment rate.

\section{References}

Aydemir, A., and M. Skuterud. 2005. Explaining the deteriorating entry earnings of Canada's immigrant cohorts: 1966-2000. Canadian Journal of Economics 38(2):641-672.

Beaudry, P., and D. Green. 2000. Cohort patterns in Canadian earnings: Assessing the role of skill premia in inequality trends. Canadian Journal of Economics 33:907-936.

Bloom, D.E., G. Grenier, and M. Gunderson. 1995. The changing labour market position of Canadian immigrants. Canadian Journal of Economics 28:987-1005. 
Hou: Immigrant entry earnings over the past quarter-century

Boudarbat, B., and T. Lemieux. 2010. Why are the relative wages of immigrants declining? A distributional approach. Canadian Labour Market and Skills Researcher Network (CLSRN) Working Paper No 65.

Boudarbat, B., T. Lemieux, and C. Riddell. 2010. Evolution of the returns to human capital in Canada, 1980-2005. Canadian Labour Market and Skills Researcher Network (CLSRN) Working Paper No. 53.

Frenette, M., and R. Morissette. 2005. Will they ever converge? Earnings of immigrant and Canadianborn workers over the last two decades. International Migration Review 39:228-258.

Green, A., and D. Green. 1999. The economic goals of Canada's immigration policy: Past and present. Canadian Public Policy 25(4):425-451.

Green, D., and C. Worswick. 2004. Immigrant earnings profiles in the presence of human capital investment: Measuring cohort and macro effects. Institute for Fiscal Studies Working Paper No. WP04/13.

2010. Entry earnings of immigrant men in Canada: The roles of labour market entry effects and returns to foreign experience. In Canadian Immigration: Economic Evidence for a Dynamic Policy Environment, edited by T. McDonald, E. Ruddick, A. Sweetman, and C. Worswick. Montreal: McGill-Queen's University Press, pp. 77-110.

Morissette, R. 2008. Earnings in the last decade. Perspectives on Labour and Income 9(2):12-24. Ottawa: Statistics Canada.

Oaxaca, R., and M. Ransom. 1999. Identification in detailed wage decompositions. The Review of Economics and Statistics 81(1):154-157.

Picot, G., and F. Hou. 2003. The rise in low-income rates among immigrants in Canada. Statistics Canada: Analytical Studies Branch Research Paper Series No. 198, Ottawa.

- 2009. Immigrant selection, the IT bust and entry earnings of immigrants in Canada. Statistics Canada Analytical Studies Research Paper Series No.315, Ottawa.

Picot, G., and A. Sweetman. 2005. The deteriorating economic welfare of immigrants and possible causes: Update 2005. Statistics Canada: Analytical Studies Branch Research Paper Series No. 262, Ottawa.

Picot, G., F. Hou, and S. Coulombe. 2008. Poverty dynamics among recent immigrants to Canada. International Migration Review 42:393-242.

Reitz, J. 2001. Immigrant success in the knowledge economy: Institutional change and the immigrant experience in Canada, 1970-1995. Journal of Social Issues 57:579-613.

- 2007a. Immigrant employment success in Canada, Part I: Individual and contextual causes. Journal of International Migration and Integration 8:11-36.

- 2007b. Immigrant employment success in Canada, Part II: Understanding the decline. Journal of International Migration and Integration 8:37-62.

Schaafsma, J., and A. Sweetman. 2001. Immigrant earnings: Age at immigration matters. Canadian Journal of Economics 34:1066-1099.

Sweetman, A. 2004. Immigrant source country school quality and Canadian labour market outcomes. Statistics Canada Analytical Studies Working Paper Series No 234, Ottawa. 